\title{
The authority of geography in Pericles, Prince of Tyre: Jacob Falckenburgk and Dionysius Periegetes
}

\author{
Monica Matei-Chesnoiu \\ Ovidius University of Constanta, Romania
}

\begin{abstract}
Taking into account the complex authorship of Pericles, Prince of Tyre, this paper surveys the intertextual influence of the Latin verse narrative of the Apollonius saga by Jacob Falckenburgk (London, 1578) and Thomas Twayne's translation of Orbis terrae descriptio (The Surveye of the world) by Dionysius Periegetes (London, 1572) on the erratic geography of Pericles. Drawing on the Pericles/Apollonius tales (the play and its Latin verse and English prose intertexts), as well as the ancient geographic narrative describing the Eastern Mediterranean spaces of the settings, the play decentres the authority of ancient geography maintained via the well-travelled Apollonius tale or through the weight of classical texts. Pericles destabilizes the authority of both classical language and geography through a process of defamiliarization of and distancing from the legitimization of ancient texts and geographic tradition. Through the suggestion of alterity during the dramatic interaction, the play incorporates the recognition of difference and the support of tolerance within early modern transnational communities.
\end{abstract}

KEYWORDS: Shakespeare; romances; geography; Latin; Falckenburgk; Periegetes; Renaissance drama. 
It might seem a hopeless or heedlessly daring task to attempt a discussion about intertextuality, or the transmigration of motifs in a play of such authorial complexity ${ }^{2}$ and oddly shaped narrative style as Pericles, Prince of Tyre. Not surprisingly, David Skeele calls Pericles "perhaps the most paradoxical of Shakespeare's plays" (2000:1), considering that paradox and the mixed mode seem to be its theatrical default modes. I will focus on the performative aspects of geography and the creation of place in Shakespeare and Wilkins's play, in the sense coined by John Gillies (2003:177) and Rob Sullivan (2011:1 $)^{3}$ as viewed from the perspective of drama. Looking at how classical geographic texts and allusions to space inflect dramatic representations of places in Pericles, my purpose is to open stillunexplored pathways into the play's generic peculiarity, in the hope of explaining some of its incongruities through the lens of geography. Discussing the cultural geography of stage romance, Cyrus Mulready explores the intersections of drama, romance, and overseas expansion, arguing that stage romances responded to the audience's interest in an emerging global empire (2013:2-3). Mulready reads The Tempest and Pericles as "presenting differing responses to geographic shifts brought on by the expanding globe" (30). Extending this argument of adaptable performative action via

\footnotetext{
I "I shall sing for reason of time and place" (Falckenburgk 1578:Aiij'), my translation.

${ }^{2}$ Since this is neither a source study nor an authorship debate, I accept the consensus for Shakespeare-Wilkins' dual authorship. See Jackson (1990:192-196; 1993:239-249; (2003); Klause (2010:395-400; 2012:538-544); Jackson (2011:260-6; 2013:434-439); McMannaway (1969:1259); Smith (1974:1479); Schanzer (1972:149); Bevington (1992:1398); Jowett (2003:117); Knapp (2009:29). Hillman sees the play as an artistic whole, whatever the circumstances of composition, through Gower's choric role (1985:427). Whether Shakespeare revised an earlier play or not, or whether Wilkins had a hand in the first acts, does not alter my discussion of the play's geographic scope in relation to Falckenburgk and Dionysius Periegetes. However, since my argument focuses mainly on Acts III and IV, considered much more Shakespearean by Jackson and McMannaway than Acts I and II, my hope is that comments on geography, space, and ethnicity will illuminate indirectly the problem of authorship.

${ }^{3}$ Gillies understands place in Shakespeare's later plays in relation to "the embodied self" and notes that "The various settings of the late plays tend, like the Near-Eastern cities of Pericles (Antioch, Tyre, Pentapolis, Tharsis, Mitilene), to be qualitatively "thin" and virtually interchangeable" (2003:177). Sullivan explores the ways in which speech act theory can be applied to geography and views the creation of place as being implicated in performance (2011:1).
} 
geographic reconstruction, ${ }^{4}$ I would add that the impact of classical geography in shaping a mental picture of dramatic space in Pericles destabilizes a stereotypical articulation of locale by encouraging the recognition of ethnic diversity. The play's geographic and ethnographic variety inflects alterity and allegorizes new ways of looking at an old world.

The particular handling of topographical tropes - common to the many variants of the Apollonius tale and to Pericles - validates the generic specificity of the prose and dramatic romance. In addition, new geographic knowledge restated the legitimacy of these foundation texts. In her attempt to recover the figurative geography of Pericles and The Comedy of Errors - which share a similarly exotic geographic space - Linda McJannet observes that "setting is operative in both plays as both a literal and a symbolic marker" (1998:87). Similarly, Roger Warren argues that the late plays of Shakespeare are united by the "spiritual journeys" undertaken by their characters (2003:8). In my view, the play's emotionally charged metaphoric space of Eastern Mediterranean locations is adapted from ancient geographers' accounts, with a particular dynamic twist specific to dramatic action. Translations from classical geographers such as Pliny, Strabo, Mela, or Solinus were widely popular in Elizabethan and Jacobean England, despite the gross inconsistencies of these reports and the advances of new geography. In the Dedicatory Epistle to Sir William Cecil, appended to his translation of Pomponius Mela's Latin geography, Arthur Golding states that the works of ancient geographers need to be revived, despite the limitations of the knowledge conveyed, because they offer readers "the pleasure of infancy" (Golding 1585:n.p.). The fictionalized and even romanticized geographic narratives transmitted from the ancients to early modern times account for the emblematic dramatizations of space in Pericles. Furthermore, next to the revered tradition of the Apollonius romances - also of classical origin and frequently reiterated in the vernacular - filiation from classical geographic accounts legitimizes the gross inconsistencies and erratic transgressions of physical space in the play.

\footnotetext{
${ }^{4}$ In exploring the dramatization of geographic space in the play I have considered essays on representations of geography in Pericles by Relihan (1992:281-299); McJannet (1998:86-106); Cormack (2001:155-180); Hanna (2002:102-131); Holland (2005:11-29); Laureano Domínguez (2009:71-97).
} 
The intricate generation of the Apollonius tales and their wide proliferation would appear to have no connection with the idea of firm authorship, whereas the story is remarkable for its persistence and stability. The long line of translations, imitations, märchen, volksbucher, sagas, romances, and ballads flow into the dramatic version of Pericles, Prince of Tyre, which maintains the inconsistent geographic locations of the original story. In retelling the classical romance tale of Apollonius of Tyre, Pericles draws on non-dramatic sources: John Gower's verse Confessio Amantis and Twyne's prose romance narrative (probably derived via a French version from the Gesta Romanorum, in a lineage parallel to Gower's). Alternatively, we might consider as an analogue the 1578 Latin verse rendition of Apollonius of Tyre, written by the Brandenburg count Jacob Falckenburgk and published in London ${ }^{5}$ - which is another example of the rich intertextuality of the Pericles stories. ${ }^{6}$ While I do not posit this particular version as another source for Pericles, I will demonstrate how these textual fountains were perpetually renewed in early modern times through a dialogic exchange among the various disciplines of cosmography and geography, just as ancient geography texts were dutifully revived by translators. In the attempt to compile, translate, comment on, and alter classical texts creatively, Renaissance scholarship throughout Europe constantly sought to recover the past in order to connect it to the future. Little did it matter that the regions described by ancient geographers no longer resembled early modern locations - sometimes not even in name; the metaphoric journey developed by geographic narratives was powerful enough to resuscitate nostalgia and dislocate creative energies. Dramatic adaptations of ancient narratives such as Pericles reveal spatial dynamism through action; the theatre displaces the legacy of ancient geography in performance. This disruption of space as laid out by the ancients exposes, I believe, Pericles' metatheatricality.

\footnotetext{
${ }^{5}$ This is the only edition of the work. The volume is inscribed in the Book Trade Directory for the year 1578, at R. G. (Richardus Grapheus), number 2373, "Jacobus Falckenburgius, Britannia sive de Appolonica [...] Encomium"(Arber 1875:5;108).

${ }^{6}$ Humphrey Newcomb argues that the entwined intertextuality in the setting of Pericles tales defeats ordinal logic and frustrates the reproductive assumptions inherent in traditional "source" studies (2009:21).
} 
In the Apollonius sequence of prose and verse romances, it is difficult to discern which variant preceded the other. Any version of the Apollonius saga might serve as an example, and I have chosen the seldom debated and infrequently mentioned Latin verse narrative by Jacob Falckenburgk (London, 1578). ${ }^{7}$ Rather than looking at the reiterated Apollonius story of this text, however, I will discuss the geographic allusions from the five-page dedication written by the German Count Jacob Falckenburgk in acclamation of Queen Elizabeth, Leicester, Sir William Cecil, Lord Burghley, and a pleiad of Oxonian personalities of the time. The Dedicatory Epistle of Falckenburgk's Latin verse rendition of the Apollonius tale, consisting of 162 Latin hexameters and signed "I. Falckenburgk, Germanus," places the English queen at the centre of a new world of geographic discovery, while reminding readers that we live exposed to "ter mille periclis." 8 The Queen is "Regina Britannos," "virtutis amatrix," "Ysabella," "Elizabetha," "Elissa;" she is also "Anglia Minerva," at once an image of Juno and Pallas, the pupil of Heroes and Mars. The hyperbolic images describing Queen Elizabeth are paralleled only by the enumeration of the lesser stars surrounding her, the earls of Leicester, Arundel, Bedford, Sussex, Derby, Kent, Huntingdon, Cumberland, Herford, Pembroke, Northumberland, Southampton, and Essex (Walter Devereux, First Earl of Essex), as

\footnotetext{
7 Bullough (1966:6, 349-374) does not include the Falckenburgk version among the possible sources. In the Introduction to the Arden edition of Pericles; Hoeniger mentions briefly this text as "Another Latin version of some interest [...]" (1963:xvii). In her Introduction to the New Arden edition Suzanne Gossett makes no mention of the Falckenburgk Latin verse narrative (2004:1-163). In the Introduction to the New Cambridge Shakespeare edition, the editors Delvecchio and Hammond do not find a place for the Falckenburgk narrative even among the lesser sources (1998:[3]). Neither does Muir mention the Falckenburgk text among the sources of Pericles (1977:254-266), nor Gesner (1970:84-90). The absence of the Latin version of the Apollonius tale from the list of sources for Pericles is the result of the fact that this is just one of many such tales proliferating in Europe. My approach from the direction of geography in the Latin story is intended to illuminate the distinctive perception of geographic space in the period rather than the consideration of a particular analogue among so many others.

8 “Nascimur \& morimur, siné spperáter adimus|Cuius certa hominú quéq; minuta latent.|Vivimus interea expositi ter mille periclis, |Hic foris ille domi, quo tribuletur, habet" (Falckenburgk 1578: sig. Aij') [We are born and we die, we approach the end in haste|Of which all the certain details of life lie hidden.|We live in the meantime exposed to three thousand perils|This one has afflictions abroad, that one has them at home (my translation)].
} 
well as Bacon, Hunsdon, ${ }^{9}$ Sidney, Cobham, Croft, and Walsingham. Marginal notes in this text, such as "Concordia nutrit amorem" [In harmony, love thrives] and "Iustitia elevat gentem" [Righteousness exalteth a nation] (sig. Aiij) add to the patriotic propaganda emanating from, paradoxically, a German count and adventurer. ${ }^{10}$ The Queen's illustrious body is placed at the centre of a global world comprising Europe, Africa, Asia, Magellan's America, and even the Cathay described by Polo (sig. Aiij $\left.{ }^{\mathrm{V}}\right)$. Falckenburgk admits that he will never be able to encompass, in his description and in imagination, the vast geographical space covered by the Queen's influence.

The ancient and well-travelled Apollonius tale - as told in Falckenburgk's Latin verse narrative - is set against the background of English aspirations of imperial dominance, connecting past and present, geography and history, real life and fictional stories. Contextualising his eulogy of England and Elizabeth, Falckenburgk equates the suffering and peregrinations of Apollonius with the perils of the biblical prophet Jonah ("pericla IONAS"). In this way, the author connects the ambivalent geography of the Eastern Mediterranean - which is also the symbolic setting of the biblical story - with the dangers of sea-travel. A similar allusion to the story of Jonah, linked to the unpredictability of fortune during tempests at sea, echoes in the three fishermen's witty exchange in Pericles: the fishermen compare public misfortunes to the fictional tale of a huge whale that swallowed an entire parish (2.1.28-43). ${ }^{11}$ The fishermen's comical exchange plays on the tale's impossibility - perpetuated by hearsay - and is heavy with social and political allusions. In the moralizing tone specific to early modern re-interpretations of

\footnotetext{
${ }^{9}$ Henry Carey, Lord Hunsdon, as Lord Chamberlain, became the first patron of The Lord Chamberlain's Men in 1594. See Bevington (2011:27).

1o According to Jantz, "Jacob von Falckenburgk, from Brandenburg, wrote such paraphrastic poems and published a group of them in London, in the Britannia, 1578, and the Ara et Focus, 1579, at the time Johannes Casimirus of the Palatinate was there to consult with Queen Elizabeth on the defence of the Protestant cause. With their publication in England, they have escaped the attention of the German literary scholar. And indeed, no special attention has been given to this dualistic kind of composition, at its best held together by fascinatingly intricate filiations running back and forth between the two layers of action" (1966:434).

${ }^{11}$ My references to the controversial text of Pericles, Prince of Tyre are keyed to the New Arden edition, ed. Suzanne Gossett (2004).
} 
classical stories, Falckenburgk claims that he would bring into the present the message of ancient exemplary acts, declaring that his poetic argument is directed to a specific time and place ("Temporis atque loci pro ratione canam," Aiij'), namely the Elizabethan London he seemed to admire so much. Considering that Pericles is the only one of the hundreds of versions ${ }^{12}$ of the Apollonius narrative to change the protagonist's name, I might draw attention to this variant in relation to the possible influence of the Latin word for "perils" (periclis) in the configuration of the play. However, since I do not hypothesize that the Falckenburgk variant of the Apollonius story is a possible source for Pericles, I prefer to highlight the extensive geographic scope of the traditional Apollonius tale, which is superimposed on Falckenburgk's presentation of Elizabeth's figure at the centre of an increasingly better-known world, thus prefiguring England's imperialistic aspirations. Geopolitics, geography, and history are entwined to suggest new possibilities of expansion and domination by a beneficial rule, such as Elizabeth's is considered to be in Falckenburgk's encomium.

Romance stories in early modern England provided the kind of imaginative provocation also found in classical geography texts. The allure of both romance and ancient geography served as a powerful enticement to territorial and colonial involvement. I propose then that the dramatic romance represented by Pericles developed from its roots in medieval narrative into a stage genre that dramatized both the ancient geography of an old world and the new imperial aspirations of an Elizabethan and Jacobean globalized sphere. In this context, geographic locations described by ancient writers coexisted with a pragmatic dramatization of trade and travel, as suggested in the play's scenes in Mytilene. The text I have selected from the large number of classical geographic works published in the period 15721609 is Thomas Twyne's 47-page prose translation of Orbis terrae descriptio (The Surveye of the world) by Dionysius Periegetes (1572). ${ }^{13}$

\footnotetext{
${ }^{12}$ For further reference to the extension of the Apollonius narrative, see Smith (1972); Archibald gives only a brief survey of the versions of the Apollonius story produced up to 1609, the year of publication of the quarto of Pericles, admitting/acknowledging that there are too many to be described in detail (1991:182).

${ }^{13}$ The full title of Twyne's translation of Dionysius Periegetes is The surueye of the voorld, or situation of the earth, so muche as is inhabited Comprysing briefely the generall partes thereof, with the names both new and olde, of the principal countries, kingdoms, peoples, cities, towns, portes, promontories, hils, woods, mountains, valleyes, riuers and fountains
} 
Thomas Twyne was the brother of Lawrence Twyne, the author of The Patterne of Painefull Adventures (1576), ${ }^{14}$ which tells the story of Apollonius, prince of Tyre. ${ }^{15}$ The English translation from Dionysius Periegetes is dedicated to William Lovelace, Esq. ${ }^{16}$ and dated London, 15 May 1572 (ij). The title page bears the motto "Armipotenti Angliae" [England's power in arms], suggesting images of military supremacy. Replaying the Elizabethans' interest in the expansion of geographic knowledge for political and imperialistic reasons, as well as the early Jacobean encouragement of the new geography, the play dissolves the authority of ancient geography maintained via the well-travelled Apollonius tale and classical geographic texts.

In his introduction to the translation of Dionysius Periegetes, Twyne mentions that he has added the current names of the countries to the original Latin ones in order to make the classical text more accessible to the reader. Latin is the initial common vehicle for the propagation of knowledge in the narrative romance and the ancient description of the world, while the dramatic romance apparently shares similar interconnected roots emerging from discourses of Roman imperial dominance. Rome's colonial power asserted its supremacy not only by military might but also by the geographic knowledge that the empire's scholars could produce. Dionysius Periegetes, or "the Traveller, the Voyager," probably lived

therin conteyned. Also of seas, with their clyffes, reaches, turnings, elbows, quicksands, rocks, flattes, shelues and shoares. A work very necessary and delectable for students of geographie, saylers, and others. First voritten in Greeke by Dionise Alexandrine, and novv englished by Thomas Twine, Gentl. Imprinted at London: By Henrie Bynneman, Anno. 1572. STC 6901. Emphasizing the practical and wide scope of the geographic text, the translator inscribes it among the works necessary for any person's education, but never mentions the fact that it was already outdated at the time of its translation.

${ }^{14}$ The Patterne of Painefull Adventures by Laurence Twine was entered in the Stationers' Register in 1576 and is extant now in two editions, one undated but possibly c. 1594 and the other of 1607 (when it was attributed to Thomas Twine, Laurence's brother). Discussing the geographic scope of this prose romance, Relihan observes that the significance of Twine's world is "because of its emphasis on creating spaces not through didactic description of customs or natural history, but through an emphasis on the civic dimension of the locations in which it is set" (2004:79).

${ }^{15}$ The Patterne has been several times erroneously ascribed to Thomas Twyne, but this is irrelevant in the context of this study.

${ }^{16}$ Sir William Lovelace the Elder (1561-1629), sergeant-at-law, was a barrister and the grandfather of the Cavalier poet Richard Lovelace. See Elton (1986:101) for evidence concerning Sir William Lovelace, who was recorded as speaking as MP in 1571, a year before this translation from Dionysius Periegetes by Thomas Twyne was published. 
in the time of Emperor Hadrian, in the second century AD. He wrote the description of the then known world in Greek hexameters, but the purpose was to prove ancient Rome's incontestable cultural supremacy. When describing the inhabitants of the Italian peninsula, Dionysius mentions "the Latini, a glorious kinde of people, verie plentifull with goodnesse of soile and excellencie of wits" (sig. Bv $\left.{ }^{r}\right)$. Roman imperial governance is incontestably connected with the spreading of knowledge through Latin (and implicitly Greek) as the languages of culture, which were also instrumental in the dissemination of geographic knowledge. In most ancient geographic texts, therefore, the centrality of Rome at the heart of the empire was dutifully emphasized, while Latin was the universal language of scholarly communication, as it was in Renaissance Europe.

It was through Latin that Falckenburgk could convey his flattering eulogy to Elizabethan learned readers, and Latin was also the language that made possible the transmission of geographic information encoded in Orbis terrae descriptio by Dionysius Periegetes. The authority of Latin emerges in Pericles through the intercession of Gower's commendation of old things as better than new ones (1.0.10), as well as in the five mottos of the knights contending for Thaisa's hand at the mock-medieval tournament $(2.2 .21 ; 29 ; 33 ; 38 ; 43)$. The educated readers of geography texts would expect to find Latin quotations in the descriptions of ancient places, while the presence of Latin in the play highlights the antiquity of the story and the globalized perspective suggested by visions of empires, past and present. In the dedication "To the Friendly Reader" Twyne explains that the text of Dionysius of Alexandria was written initially in Greek and later translated into Latin. There are several conjectural references to "authority" in Twyne's address to the reader, which might illumine the kind of Renaissance intertextuality that made such composite stories possible: the "olde writer" (Dionysius) was commended in antiquity "for compendiousness and brevity"; although many of his descriptions can also be read in Pliny, the translator notes, "sufficẽt it shal be in prayse or authority to have yealded to him his owne, and no more" $\left({ }^{*} 4^{\mathrm{r}}\right)$. This is, I believe, the approach we might adopt for all Renaissance texts - in Latin or vernacular, whether literary, geographical, historical or other - when the question of authorship and the confusion generated by multiple borrowings and interpolations threaten to give us pause. We could yield each author 
his/her own and admit not only that repetition and conflation were common practices in the period, but that this intellectual exercise was no less honourable and praiseworthy for being so. Yet, we should attribute to these compilations no more praise than is due to them, in accordance with the genre of that particular work and the general rules of composition.

Dionysius's geographic text contains graphic images that require decoding with the help of imaginative and geometric abstraction - the same mental process as that involved in reading a map or needed to envisage distant locations described by ancient or contemporary geographers. Therefore, knowledge derived from geography is almost as much indebted to the visual as theatrical action is. For example, Dionysius explains the division of the Earth into continents and the fact that the known world is surrounded by the ocean like a large island; he mentions the seas and continents of Asia, Africa, and Europe, the three corners of the known world in ancient geography. In the chapter describing "The Situation of Europe," Dionysius gives a graphic presentation of the continent, shaped "lyke the pointe of a triangle, waxing alwayes narrower towards the West, and encreasing in widnesse much in the East" $($ sig. Bij $)$. This cartographic image is impressive, considering that we owe it to an ancient geographer who is known to have never travelled to the regions he describes, according to his own testimony. Dionysius's visual depiction of Europe implies that he must have had access to a bird's eye view of the continent, which is remarkable when we consider the ancients' supposedly limited knowledge of the world. Renaissance geographers liked to think that they added to the world's knowledge, whereas we see that classical texts could map the ancient world with the kind of visual accuracy that we can ascribe only to later early modern cartography devised according to the Mercator projection. In a non-fictional geographic text, therefore, the author offers a telescoping perspective through visual geometric projection, while the playwright(s) would use Gower's intercession to highlight mise-en-abyme and theatricality.

Despite the antiquated flavour suggested through Gower's choric interventions, these dramatic shortcuts compress time and space in a manner possible only in theatre. For example, in all the recurrent Apollonius tales, a storm strikes the despondent hero for the third time when he lands in Mytilene. In Pericles, Gower's 
narrative gives profundity to this episode by informing the audience: "[...] we left him on the sea. We there him lost,|Whence, driven before the winds, he is arrived|Here where his daughter dwells" (5.0.13-15). The here and now of performance is the city of Mytilene, which is celebrating God Neptune's annual feast. The sea, tempestuous winds, and fortune are connected, in the same way as in the source variants of the story, with the particular addition of performativity. In a gesture of theatrical self-reflexivity similar to the Prologue in Henry $V$ inviting the audience to visualize the "vasty" fields of France, Gower encourages the audience to imagine how Pericles' party had anchored at Mytilene and to picture the setting of his ship, while announcing that further events will be discovered "in action" (5.0.23). Gower carefully delimits the performance space: after Pericles was shipwrecked on the shore of Pentapolis, Gower declares, "here he comes" (2.0.39), while later he invites the audience to "Imagine Pericles arrived at Tyre" (4.0.1). Even more so, during the storm in which Marina is born, Gower breaks up the narrative and proclaims that the action "Shall for itself itself perform" (3.0.54); he appeals to the audience's "imagination" to visualize "This stage the ship" (3.0.59). In this way, narrative and geographic space becomes theatrical space. Just as, in the source stories, the symbols of the sea and the tempest as agents of fortune emphasize the inherent flexibility of a romance tale that has gone through centuries practically unscathed (and yet forever rendered different), the dramatic version of the Pericles tales highlights the here and now of performance in action.

The tradition that conjoins the Apollonius narratives involves asynchronous collaboration and a multiplicity of texts. Moreover, in drama, audiences are confronted with multifaceted and volatile realities of performance. Gower invites the audience to imagine and visualize space, just as when reading a map or a geographic narrative. A similar telescoping image suggesting the mental picture of a ship approaching the cliffs of Mytilene surfaces from Dionysius's geography. Visualizing the description of the Greek islands to his readers, the ancient author offers a navigator's view of the Aegean islands, "Lesbos, now Metelina," and Tenedo; their cliffs rise high out of the water. Two rivers, Melas and Colphus, run into Hellespontus, and from there, to the north, lies the Sea Propontis, which enlarges then on every side and forms the entrance to the Sea Euxinum (sig. Ciii ${ }^{\mathrm{V}}$ ). By imagining a ship that approaches the cliffs of 
Mytilene as described by Periegetes, the reader can summon a similar image with the one formed in the minds of members of the audience of Pericles; they are able to visualize Gower's description of the Tyre ship approaching the shores of Mytilene, expecting to have the rest of the story revealed in action. Lisa Hopkins refers to the play's theatrical "blurring of person and place," and cogently argues that the geographic locations dramatized in Pericles reveal "a Greece of the mind" (2000:228); Indeed, imaginative capacity in drama works differently than do the visions of expanded spaces emerging from ancient geographic descriptions. Both need to abstract narrative and compress space. While the latter encompass huge spaces and rely on the locations' names and, sometimes, geographic coordinates of latitude and longitude for specification, drama relies on the present viewer's perspective.

Both early modern geography texts and drama, when they offer a perception of vast spaces, create shortcuts for the reader/audience and give them a condensed glimpse of the places described. Imaginative capacity for abstraction and representation is necessary in both cases. Like Elizabethan or Jacobean playwrights, classical geographers did not (and could not) necessarily travel to the locations they represented. Travel was mostly in the mind, and with the help of learning from other authors. For example, Dionysius describes the areas of the Sea Caspium (Caspian Sea) in his geography. Admitting that he did not travel to faraway regions such as these, Dionysius depicts the lands unknown to him "not as one that hath séene those places (by traueling [...]), but like him who from his tender yeares, hath ben brought $\mathrm{vp}$ in studie of good learning, whereby it commeth now to passe, that those things whiche are very farre distant, I doe beholde as present, and can conceyue euery place throughly in my mynde and cogitation without any errour" (sig. Dy ${ }^{r}$ ). Time and place can be thus transgressed with the help of learning and imagination. Discussing the creative referentiality of constructed spaces in ancient geography, Bertrand Westphal gives the example of the "macroscopic" descriptions by Periegetes. As Westphal observes, "Dionysius probably had not been a traveler, or even a cartographer: he traveled the world through the mind, through the text, through a text that he wrote in the form of inventory. The connection between text and space is close here; it passes through the power of speech, which creates spaces" (2011:81). Ancient and early modern 
geographic texts were a blend of allusions to classical mythology, natural philosophy, wonder stories, and hearsay. Such was the way of writing geography in ancient times, as in Elizabethan and Jacobean England. As in ancient geographic narratives, Gower is testimony to the power of speech to create space, but audiences can also see that stage space speaks for itself.

Pericles is, thus, the result of combined influences of romance tradition, ancient and early modern geographic narratives, and compressed dramatic action. Through the force of repetition, ancient and early modern geographic descriptions created cultural clichés perpetuated throughout the concatenation of various discourses about a certain place. However, in Pericles, the stereotypical characteristics that proliferated in geographic and ethnographic texts about Eastern Mediterranean nations are blurred and inconsistent. Indeed, the hero is a descendant of the intrepid Phoenician seafarers but his purpose is not clear and he wanders aimlessly around the prescribed locations, apparently a victim of capricious fortune, as in the Apollonius story. When describing the third part of Asia and the Eastern Mediterranean cities, Dyonisius Periegetes praises the Phoenicians, based in the ancient city of Tyre: "the fayre and auncient citie Tyrus, nowe Sur, builded from the beginning" (sig. $C^{r}$ ). The inhabitants are famed to have been the first navigators and traders and to have found the motions of the stars, "by the excellencie of their witte and industrie" (sig. $\left.\mathrm{Ci}^{\mathrm{v}}\right)$. There is almost no trace of the famed Phoenician diligence and determination in the melancholy prince shipwrecked on the coast of Pentapolis, possibly in the North African province of Cyrenaica. Pericles experiences the events of his life as things that have happened to him, rather than things that he has had a hand in carrying out. This emphasizes the instability of fortune, as in the Apollonius narrative, and the character is reminiscent of Jonah, except he has no real faith, and therefore seems to have no real moral or psychological reason to believe the way he does. On the other hand, the renowned Phoenician intrepidity and business spirit surfaces in the play through the verbal interactions among the fishermen on the coast of Pentapolis, or among Bawd, Pander, and Boult in Mytilene - an interesting economic banter suggestive of international trade.

The contingency of the space in which dramatic action develops derives from the unsituatedness of the romance genre, but the play 
also suggests matter-of-fact localization targeted at a specific time and place - possibly Jacobean England. Pericles, for instance, is treated by Thomas Roebuck and Laurie Maguire as a play about British nationhood - a preoccupation signalled, above all, in the play's language and the figure of Gower (2010:24). More specifically, David Morrow examines Pericles through the lens of the social changes brought about by capitalist circulation and commodity exchange in Jacobean England as a result of travel and global traffic (2013:356). Even more so, as I note, the ethnic blend and cosmopolitanism of the city on the island of Lesbos contrasts with the play's indefinable geography of the Eastern Mediterranean, inherited from the Apollonius tale and ancient geographic narratives. In the brothel scene of Pericles, the Bawd's allusions to the already dead Transylvanian (4.2.19-20), the lecherous Spaniard (4.2.91-92) and the diseased French knight, Monsieur Veroles (4.2.98101) provide a local contrast to the vague Hellenistic atmosphere of the Apollonius stories. Only the dramatic romance displays these allusions to early modern European nations, non-existent at the time of the classical source stories. By integrating members of Eastern and Western European nations in the unruly sociality of the brothel, the play dislocates the fictionalized view inherited from romance story and classical geography, representing a world of consumer mobility and trade similar to that of Jacobean London. In this way, geography speaks on stage with the language of economics and commercial enterprise.

There may be a fresh and commercially enabling geographic language expressed through the interactive references to the three foreigners from the Mytilene brothel, but each individual reacts differently to the mixed social context in the city. By definition, the brothel space is a site of anonymous commercial interchange, where sex is a commodity, across race and ethnic boundaries. As the cynical Bawd tells Marina, she is expected to "taste gentlemen of all fashions" and "have the difference of all complexions" (4.2.72; 73). Not only does the Bawd wish to have "of every nation a traveller" (4.2.104) hooked to the description of Marina's charms, but it is obvious that they already had three foreigners. It is inferred that all three men were the victims of the "poor three" (4.2.7) diseased prostitutes at the brothel. Exploring the medical and social contexts of syphilis on the Renaissance stage, Margaret Healy sees the representation of the disease in Pericles as "a powerful stage vehicle 
for coded comment and dissent" (2001:153). Indeed, theatrical comment about the sociality of the pox is present, but foreigners react differently to its effects. According to Pander, the "poor Transylvanian" (4.2.19) is dead, he is already "roast meat for worms" (4.2.30-31), as Boult says, so he has atoned for his sins. One can even detect a note of compassion in the remarks of the hardened procurers who intermediate sex for money. The representation of the lecherous Spaniard, with his ruff and affected manner, whose mouth watered at the description of Marina's charms, appears to correspond to the cliché propagated by ethnographic texts. This particular Spaniard, however, has a great imaginative capacity because, according to Boult, "he went to bed to her very description" (4.2.92-93). Nor was the diseased Frenchman less enthusiastic to meet Marina after hearing Bolt's "proclamation" of her beauty; he wanted to cut a caper but was prevented by his genital ailment from doing so (4.2.99-100). The audiences can see how the apparently incongruous presence of members of three European nations in the cosmopolitan brothel of Mytilene configures a stage geography that destabilizes romanticized notions about love gleaned from popular romance stories, or vague views of Mediterranean spaces inspired by ancient narratives.

The brothel in Mytilene allegorizes a communal space of hardhearted commercial enterprise, much like Elizabethan and Jacobean London, where international communities engage in productive commercial traffic. In a debate about economic practices mirrored through the flexible genre of tragicomedy, Valerie Forman observes: "Pericles explores the possibilities of expanding economically by expanding geographically" (2008:64). There is a constant dialectic in the play between insularity and expansion, opposing terms in the debate about commercial contact with distant countries and cultures. A topical allusion in the brothel scene in Pericles refers to the gold "chequins"17 (4.2.32) and entitles us to acknowledge "the distinctly English feel of the scene" (Cohen 1997:2757n4). In the curiously commercial conversation between pimp and bawd, it is understood that Pander intends to make "three or four thousand chequins" (4.2.32) and then retire from the business, while Bawd does not seem

\footnotetext{
${ }^{17}$ The sequin (Italian zecchino) is a gold coin minted by the Republic of Venice from the thirteenth century onwards, which remained unchanged for five hundred years. In 1478, the Ottoman Empire introduced a similar unit (Pamuk 2000:60-61).
} 
to agree. Since the Eastern Mediterranean locations of Pericles' peregrinations were part of the Ottoman Empire in Shakespeare's time, including the island of Lesbos, the monetary reference has political connotations. According to Alfred C. Wood, the English ambassador at Constantinople, Henry Lello (a former factor in the Levant Company), who left Constantinople on May 24, 1607, was paid three thousand chequins per annum as a member of the merchant company, and so was his predecessor, Edward Barton (2006:80, 85). The incongruous location of Mytilene, on the island of Lesbos, which suggests antiquated echoes of classical Greek poetry (through the poetess Sappho) and appears to belong to an equivocal Hellenistic world, is also dramatized as a version of early modern Constantinople. The Ottoman capital suggests commercial enterprise and lucrative Anglo-Turkish diplomatic relations. Moreover, the dead Transylvanian comes from one of the three principalities, north of the Danube, under Ottoman influence in the late sixteenth- and early seventeenth century, Wallachia, Moldavia, and Transylvania; not to mention that the diplomatic ballet in Constantinople included tense or more relaxed associations with Spain and France; these countries had diverging interests in relation to the Ottoman Empire. While Spain competed with the Ottomans for supremacy in the Mediterranean, France and England competed with each other for influence with the Sultan.

In the social, political, and commercial vortex at play that mingles classical and early modern geographical knowledge, romance modes, and submerged Latin echoes, Pericles disrupts the authority of both classical language and geography through a process of defamiliarization, distancing itself from the sanction of ancient stories and geographic tradition. The play evokes alterity implied through the presence of early modern European nations in the social milieu of the brothel - and incorporates recognition of difference and support of tolerance within the early modern transnational communities. The Transylvanian, the Spaniard, and the Frenchman in Pericles appear to be characterized by ethnic stereotypes ascribed to each nation in early modern geographic texts: the Transylvanian is the typical foreigner, ${ }^{18}$ the Spaniard is lecherous

\footnotetext{
${ }^{18}$ As Gossett marginally observes in a note referring to the Transylvanian in the brothel scene (4.2.19), "the evil of prostitution is associated with foreigners" (2004:324 n19).
} 
and affected; while the Frenchman displays the lascivious inclinations epitomized through the notorious "French" disease. However, all of them are united by mutual suffering in the cosmopolitan sociality of the brothel. Not only is the Spaniard able to recreate Marina's beauty in his imagination, and the Frenchman happy to dance in eager expectation of an encounter with her, but the Transylvanian's absence adduces echoes of repentance and redemption in death. Objectionable physical and behavioural traits traditionally ascribed to "foreigners" are counterbalanced with hints of spirituality and vulnerability. In a play that conflates geographic locations and gods of an ambiguous Hellenistic world with a territory suggesting the contemporary conflict between Christendom and the Ottoman Empire, the three European nations are dramatized as contingent and historical constructions. Whereas the ancient geographic text by Dionysius Periegetes and Falkenburgk's preface dedicated to various English patrons (including Queen Elizabeth) eulogize English intrepidity and place the monarch at the centre of world power, the play - though quintessentially English - allows for multifaceted diversity.

\section{References}

Arber, Edward, ed. 1875. A Transcript of the Registers of the Company of Stationers of London; 1554-1640 A.D. Vol. 5. Birmingham: Privately Printed.

Archibald, Elizabeth 1991. Apollonius of Tyre: Medieval and Renaissance Themes and Variations: Including the Text of the "Historia Apollonii Regi Tyri" with an English Translation. Cambridge: D. S. Brewer.

Bevington, David 2011. Murder Most Foul: Hamlet through the Ages. Oxford: Oxford University Press.

Bullough, Geoffrey 1966 (1957). Narrative and Dramatic Sources of Shakespeare. Vol. VI. London: Routledge.

Cohen, Walter 1997. "A Reconstructed Text of Pericles, Prince of Tyre." Ed. Stephen Greenblatt et al. The Norton Shakespeare: Based on the Oxford Edition. New York: Norton: 2709-2718.

Cormack, Bradin 2001. "Marginal Waters: Pericles and the Idea of Jurisdiction." Ed. Arthur Gordon and Bernhard Klein. Literature, Mapping, and the Politics of Space in Early Modern Britain. Cambridge and New York: Cambridge University Press: 155-180. 
Delvecchio, Doreen and Antony Hammond, eds. 1998. Introduction. Pericles. The New Cambridge Shakespeare. Cambridge: Cambridge University Press: $1-78$.

Elton, Geoffrey R. 1986. Parliament of England, 1559-1581. Cambridge: Cambridge University Press.

Falckenburgk, Jacob 1578. Jacobi à Falckenburgk, Saxonis Brandenburgi, Britannia sive de Apollonica humilitatis, virtvtis et honoris porta. Libri 4. London: R. Graphei [R. Schilders]. STC 10674.

Forman, Valerie 2008. "The Voyage Out: Pericles." Tragicomic Redemptions: Global Economics and the Early Modern English Stage. Philadelphia, PA: University of Pennsylvania Press, Inc.: 64-84.

Gesner, Carol 1970. Shakespeare and the Greek Romance. Lexington: The University Press of Kentucky.

Gillies, John 2003. "Place and Space in Three Late Plays." Eds. Richard Dutton and Jean Howard. Companion to Shakespeare's Works: The Poems, Problem Comedies, Late Plays. Oxford: Blackwell: 175-193.

Golding, Arthur 1585. "Epistle Dedicatorie to Sir William Cecil, Lord Burgley." Pomponius Mela. The vvorke of Pomponius Mela. London: John Charlewood for Thomas Hacket. Not paginated. STC 17785.

Gossett, Suzanne, ed. 2004. Introduction. Pericles. New Arden Shakespeare. London: Thomson Learning: 1-163.

Hanna, Sara 2002. "Studying Pericles through Sacred Geography, or Sailing to Paradise." Ed. Beatrice E. Batson. Selected Comedies and Late Romances of Shakespeare from a Christian Perspective. Lewiston and Lampeter: Mellen Press: 102-131.

Healy, Margaret 2001. Fictions of Disease in Early Modern England: Bodies, Plagues, and Politics. Basingstoke: Palgrave Macmillan.

Hillman, Richard 1985. "Shakespeare's Gower and Gower's Shakespeare: The Larger Debt of Pericles." Shakespeare Quarterly 36/2: 427-437.

Hoeniger, F. David 1963. Introduction. Pericles. The Arden Edition of the Works of William Shakespeare. London: Methuen: xiii-xci.

Holland, Peter 2005. "Coasting in the Mediterranean: The Journeyings of Pericles." Angles on the English-Speaking World 5: 11-29.

Hopkins, Lisa 2000. "'The Shores of My Mortality': Pericles' Greece of the Mind." Pericles: Critical Essays. Ed. David Skeele. New York: Garland Publishing: 228-237.

Humphrey Newcomb, Lori 2009. "The Sources of Romance, the Generation of Stories and the Patterns of the Pericles Tales." Eds. Mary Ellen Lamb and Valerie Wayne. Staging Early Modern Romance: Prose Fiction, Dramatic Romance, and Shakespeare. London: Routledge: 21-48. 
(c) ederi 24 (2014)

Jackson, Mac D.P. 1990. "Pericles, Acts I and II: New Evidence for George Wilkins." Notes and Queries 37/1: 192-196.

— 1993. "Rhyming in Pericles: More Evidence of Dual Authorship." Studies in Bibliography 46: 239-249.

2003. Defining Shakespeare: Pericles as test Case. Oxford and New York: Oxford University Press.

- 2011. "Rhymes and Authors: Shakespeare, Wilkins, and Pericles." Notes and Queries 58/2: 260-266.

- 2013. "Reasoning about Rhyme: George Wilkins and Pericles." Notes and Queries 6o/3: 434-439.

Jantz, Harold 1966. "German Renaissance Literature." MLN 81/4: 398-436.

Jowett, John 2003. "Varieties of Collaboration in Shakespeare's Problem Plays and Late Plays." Eds. Richard Dutton and Jean Howard. Companion to Shakespeare's Works: The Poems, Problem Comedies, Late Plays. Oxford: Blackwell: 106-128.

Klause, John 2010. "Rhyme and the Authorship of Pericles." Notes and Queries 57/3: 395-400.

- 2012. "A Controversy over Rhyme and Authorship in Pericles." Notes and Queries 59/4: 538-544.

Knapp, Jeffrey 2009. Shakespeare Only. Chicago: University of Chicago Press.

Laureano Domínguez, Lorena 2009. "Pericles' 'unknown travels': The Dimensions of Geography in Shakespeare's Pericles." SEDERI: Yearbook of the Spanish and Portuguese Society for English Renaissance Studies 19: 71-97.

McJannet, Linda 1998. "Genre and Geography: The Eastern Mediterranean in Pericles and The Comedy of Errors." Ed. John Gillies and Virginia Mason Vaughan. Playing the Globe: Genre and Geography in English Renaissance Drama. Cranbury, NJ: Associated University Press: 86-106.

Mela, Pomponius 1585. The vvorke of Pomponius Mela. The Cosmographer, concerninge the situation of the world wherein euery parte, is deuided by it selfe in most perfect manner, as appeareth in the Table at the ende of the booke. A booke right plesant and profitable for all sortes of men: but speciallie for Gentlemen, Marchants, Mariners, and Trauellers, translated out of Latine by Arthur Golding Gentleman. London: John Charlewood for Thomas Hacket. STC 17785 .

Morrow, David 2013. "Local/Global Pericles: International Storytelling, Domestic Social Relations, Capitalism." Ed. Jyotsna G. Singh. A Companion to the Global Renaissance: English Literature and Culture in the Era of Expansion. Blackwell Companions to Literature and Culture. Oxford: Wiley-Blackwell: 356-377.

Muir, Kenneth 1977. The Sources of Shakespeare's Plays. London: Methuen. 
Mulready, Cyrus 2013. Romance on the Early Modern Stage: English Expansion Before and After Shakespeare. Basingstoke: Palgrave Macmillan.

Pamuk, Şevket 200o. A Monetary History of the Ottoman Empire. Cambridge Studies in Islamic Civilization. Cambridge: Cambridge University Press.

Periegetes, Dionysius 1572. The surueye of the vvorld. London: Henrie Bynneman. STC 6901.

Plutarch, 1941. The lives of the Noble Grecians and Romans by Plutarch of Cheronea. In the Superb and Rare Translation by Sir Thomas North. New York: The Heritage Press.

Relihan, Constance C 1992. "Liminal Geography: Pericles and the Politics of Place." Philological Quarterly 71: 281-299.

- 2004. Cosmographical Glasses: Geographic Discourse, Gender, and Elizabethan Fiction. Kent and London: The Kent State University Press.

Roebuck, Thomas and Laurie Maguire 2010. "Pericles and the Language of National Origins." Eds. Willy Malley and Margaret Tudeau-Clayton. This England, That Shakespeare: New Angles on Englishness and the Bard. Farnham: Ashgate Publishing Limited: 23-48.

Shakespeare, William 1969. Pericles Prince of Tyre. Gen. ed. Alfred Harbage. Ed. James G. McMannaway. The Complete Pelican Shakespeare. London: The Penguin Press.

1972. Pericles, Prince of Tyre. Gen. ed. Sylvan Barnet. Ed. Ernest Schanzer. The Signet Classic Shakespeare. San Diego: Harcourt Brace Jovanovich Publishers.

— 1974. Pericles, Prince of Tyre. Gen. ed. G. Blakemore Evans. Ed. Hallet Smith. The Riverside Shakespeare. Boston: Houghton Mifflin Company.

- 1992. Pericles, Prince of Tyre, The Complete Works of Shakespeare. Ed. David Bevington. 4th ed. New York: Harper \& Collins Publishers.

— 1997. Pericles, Prince of Tyre. Ed. Stephen Greenblatt et al. The Norton Shakespeare. New York: W. W. Norton \& Company.

- 2004. Pericles. Ed. Suzanne Gossett. New Arden Shakespeare. London: Thomson Learning.

Skeele, David, ed. 2000. Pericles: Critical Essays. New York: Garland Publishing.

Smith, Albert H. 1972 (1898). Shakespeare's "Pericles" and Apollonius of Tyre: A Study in Comparative Literature. New York: AMS Press.

Solinus, Caius Julius 1587. The excellent and pleasant worke of Iulius Solinus Polyhistor Contayning the noble actions of humaine creatures, the secretes $\mathcal{E}$ prouidence of nature, the description of countries, the maners of the people: with many meruailous things and strange antiquities, seruing for the benefitt and 


$$
\text { (a) ederi 24 (2014) }
$$

recreation of all sorts of persons. Translated out of Latin into English, by Arthur Golding. Gent. London: I. Charlewoode for Thomas Hacket. STC 22896.5.

Sullivan, Rob 2011. Geography Speaks: Performative Aspects of Geography. Farnham: Ashgate Publishing Limited.

Twyne, Lawrence 1594. The patterne of painefull aduentures. London: Valentine Simmes for Newman. STC 709.

Warren, Roger 2003. Introduction. A Reconstructed Text of Pericles, Prince of Tyre. Ed. Roger Warren. The Oxford Shakespeare. Oxford: Oxford University Press: 1-80.

Westphal, Bertrand 2011. Geocriticism: Real and Fictional Spaces. Trans. Robert T. Tally Jr. New York: Palgrave Macmillan.

Wood, Alfred C. 2006 (1935). A History of the Levant Company. London: Frank Cass and Co.

How to cite this article:

Matei-Chesnoiu, Monica. "The authority of geography in Pericles, Prince of Tyre: Jacob Falckenburgk and Dionysius Periegetes." SEDERI 24 (2014): 119-139. Author's contact: mchesnoiu@gmail.com Submission: 23/11/2013 Acceptance: 23/6/2014 